\title{
Plasma Profiles of Growth Hormone, Prolactin and Insulin-like Growth Factor-I during Gestation, Lactation and the Neonatal Period in Goats
}

\author{
Tsutomu HASHIZUME, Yuuko TAKAHASHI, Megumi NUMATA, Koichi SASAKI, \\ Kimiko UENO, Kenji OHTSUKI, Mami KAWAI and Aya ISHII
}

Laboratory of Animal Breeding and Reproduction, Faculty of Agriculture, Iwate

University, Ueda 3, Morioka 020-8550, Japan

\begin{abstract}
The objectives of this research were to characterize plasma profiles of growth hormone $(\mathrm{GH})$, prolactin (PRL) and insulin-like growth factor-I (IGF-I) during gestation and the lactation period in goats, as well as in their suckling growing kids. There were no obvious changes in the GH or PRL profiles during gestation, but secretion of both GH and PRL increased acutely after parturition. The elevated GH concentrations were maintained until 3 months after parturition, whereas the PRL concentrations decreased gradually after parturition. The elevated hormone concentrations are thought to be caused mainly by an increase in the secretory pulse amplitudes. In contrast to the GH and PRL profiles, the plasma IGF-I concentrations during late gestation were significantly higher than the post-parturition concentrations, and the IGF-I concentrations in late gestation decreased gradually until the day of parturition. The plasma GH, PRL and IGF-I concentrations in kids 1 week after birth were high, and concentrations of each hormone decreased thereafter. These results show that the increased secretory potencies of pituitary GH and PRL after parturition are caused mainly by an increase in the secretory pulse amplitudes and that plasma GH is inversely related to plasma IGF-I compared over gestation and the lactation period in goats.
\end{abstract}

Key words: GH, PRL, IGF-I, Gestation, Lactation.

(J. Reprod. Dev. 45: 273-281, 1999)

G estation is a composite of integrated processes, resulting in the successful development of fetuses and the birth of offspring. The energy and nutrient requirements in pregnant animals are increased during gestation [1]. The survival of newborn animals is dependent on an adequate supply of milk secreted from the mammary glands of the mother after parturition [2]. Since growth hormone $(\mathrm{GH})$ regulates many aspects of metabolic activity [3], it is meaningful to examine the $\mathrm{GH}$ profiles throughout gestation and during the lactation period in animals. Plasma or serum

Accepted for publication: May 12, 1999

Correspondence: T. Hashizume concentrations of GH and prolactin (PRL) in ruminants have been observed to elevate acutely during the periparturient period [4-9]. In these published observations, however, blood samples were usually collected for only a few weeks around parturition, and plasma profiles of GH and PRL have never been examined throughout gestation. Moreover, the blood samples were collected only about once a day, although GH and PRL are known to be secreted in transient pulses [3,10-14]. PRL is required for the initiation of lactation $[15,16]$; therefore, it is of interest to determine how the pulsatile secretory patterns of both GH and PRL change throughout gestation and during the lactation period in animals. The anabolic action of $\mathrm{GH}$ is 
mediated by insulin-like growth factor-I (IGF-I) [3]. IGF-I profiles during gestation and the lactation period in ruminants have not been fully investigated $[9,17-20]$. The relationships among the GH, IGF-I and PRL profiles in lactating ruminants and those in their suckling young have also not been determined.

The objectives of this study were to clarify the plasma profiles of GH and PRL throughout gestation and during the lactation period in goats, and how the pulsatile secretory patterns are associated with these hormonal changes. Also, the objectives of this study were to characterize the relationships among the GH, IGF-I and PRL profiles during late gestation and the lactation period in goats and those in their suckling young.

\section{Materials and Methods}

\section{Animals}

Ten Japanese native meat-type female goats (Shiba goats) (age, 3-6 years; mean body weight, 27 $\mathrm{kg}$ ) were used. Goats were housed in pens, and natural light was allowed to enter through windows. The goats were fed hay and $100 \mathrm{~g} /$ head of concentrate from $0830 \mathrm{~h}$ to $0930 \mathrm{~h}$ and from $1630 \mathrm{~h}$ to $1730 \mathrm{~h}$ daily. Residuum of given hay was removed at each feeding time. Water was available continuously. The goats were mated from November to February. Pregnancy was diagnosed by ultrasonography and confirmed by the birth of the kids. After the parturition, the kids were housed in pens with their dams, and they were weaned 1 week after the end of all experiments (at 3 months of age). Six female and 3 male kids obtained from 6 goats were also used in the experiment. The mean gestation period and the mean number of kids born in the 10 goats were 147 days and 1.8 kids/mother, respectively. On experimental days, the goats were not fed before or during the experiment; only after the experiment.

\section{Monthly blood sampling throughout gestation and after parturition}

The episodic characteristics of GH and PRL secretory profiles throughout gestation and after parturition were examined in 4 of the 10 goats. Blood samples were collected 1, 2, 3 and 4 months after the completion of mating. The blood samples were also collected 1 week, and 1, 2 and 3 months after parturition. The jugular venous blood of the animals was taken from the indwelling catheter previously inserted into one of the external jugular veins, and the blood samples (one $\mathrm{ml}$ each) were drawn at 15-min intervals for $6 \mathrm{~h}$. The samples were obtained from $1200 \mathrm{~h}$ to $1800 \mathrm{~h}$.

\section{Weekly venipuncture samples during late gestation and after parturition}

The relationship among the GH, IGF-I and PRL profiles during late gestation and after parturition were examined in 6 of the 10 goats. The jugular venous blood samples were collected at 1 -week intervals from 3 months after mating to parturition, and samples were also collected weekly until 12 weeks after parturition. The blood samples were obtained by venipuncture between $0830 \mathrm{~h}$ and 0900h before feeding.

\section{Weekly venipuncture samples in kids}

The relationships among GH, IGF-I and PRL concentrations in growing kids were examined. Nine kids obtained from the 6 pregnant goats in the above experiment were used. Jugular venous blood samples were collected at 1-week intervals from 1 to 12 weeks after the birth. The blood samples were obtained by venipuncture between $0830 \mathrm{~h}$ and $0900 \mathrm{~h}$ independently of their suckling.

\section{Blood treatment}

Blood samples collected into centrifuge tubes containing heparin were immediately chilled with ice. Individual plasma samples were obtained after centrifugation and stored at $-20 \mathrm{C}$ until assayed.

\section{Radioimmunoassay (RIA)}

Plasma GH concentrations were measured by a double-antibody RIA [21]. The GH standard preparation and hormone for iodination was USDA-bGH-B-1. Antiserum to bovine GH (bGH) prepared in monkeys was supplied by Dr. T. Johke (National Institute of Animal Industry, Tsukuba, Japan), and goat anti-monkey IgG serum was supplied by Dr. K. Wakabayashi (Institute of Endocrinology, Gunma University, Maebashi, Japan). The intra- and interassay coefficients of variation were $4.2 \%$ and $3.1 \%$, respectively. The least detectable concentration was $1 \mathrm{ng} / \mathrm{ml}$.

Plasma PRL concentrations were measured by a double-antibody RIA procedure with slight modi- 
fication from published procedures [22]. The PRL standard preparation and hormone for iodination was NIDDK oPRL-1-3. Antiserum to ovine PRL (oPRL) prepared in rabbits was supplied by the U.S. National Hormone and Pituitary Program (NHPP, Rockville, MD, USA), and goat anti-rabbit IgG serum was supplied by Dr. K. Wakabayashi. The intra- and interassay coefficients of variation were $5.6 \%$ and $10.1 \%$, respectively. The least detectable concentration was $2.5 \mathrm{ng} / \mathrm{ml}$. The displacement curve for the increasing volume of goat plasma was parallel to the standard curve.

Plasma IGF-I concentrations were measured by a double-antibody RIA procedure with slight modification from published procedures [23]. The IGF-I standard preparation was purchased from Biomedical Technologies Inc. (Catalog No BT-106, Stoughton, MA, USA). Radioiodinated IGF-I (125IIGF-I) was purchased from Amersham (Code IM 172, Buckinghamshire, UK). Antiserum against IGF-I prepared in rabbit (UB2-495) was supplied by the U.S. National Institute of Diabetes and Digestive and Kidney Diseases (NIDDK, Bethesda, MD, USA). Goat anti-rabbit IgG serum was supplied by Dr. K. Wakabayashi. The plasma samples were first extracted with an acid-ethanol solution according to the method of Daughaday et al. [24]. The displacement curve for increasing volumes of the extract of pooled goat plasma was parallel to the standard curve. All samples were assayed in a single assay. The intraassay coefficient of variation was $1.7 \%$. The least detectable value was 14 $\mathrm{ng} / \mathrm{ml}$.

\section{Statistical analysis}

All data are presented as the mean $\pm \mathrm{SE}$. GH and PRL pulses were identified by the peak identification program known as PULSAR [25]. The G parameters used for peak identification in this study were $G(1)=4.4, G(2)=2.6, G(3)=1.92, G(4)=1.46$ and $G(5)=1.13$. These parameters followed the values reported previously [26, 27]. The significance of differences between values were analyzed by ANOVA, and that of differences between specific groups was determined by the subsequent use of the Newman-Keuls test. All data were analyzed using the GraphPad Prism program (GraphPad Software, San Diego, CA, USA) on a Macintosh.
Results were considered significant at the $\mathrm{P}<0.05$ level.

\section{Results}

Episodic hormone profiles at monthly intervals throughout gestation and after parturition

The plasma GH profiles throughout gestation and after parturition in a representative goat are shown in Fig. 1. GH was secreted in an irregular pulsatile manner in each month of gestation and after parturition. There were no obvious changes in GH profiles at each gestation age, but GH concentrations increased acutely after parturition. The mean GH concentrations at 1 week, 1 and 2 months after parturition were significantly higher than those at each gestation age $(P<0.05)$ (Fig. 2). The mean GH concentrations 3 months after parturition were significantly higher than those at each gestation age except for one month before parturi-
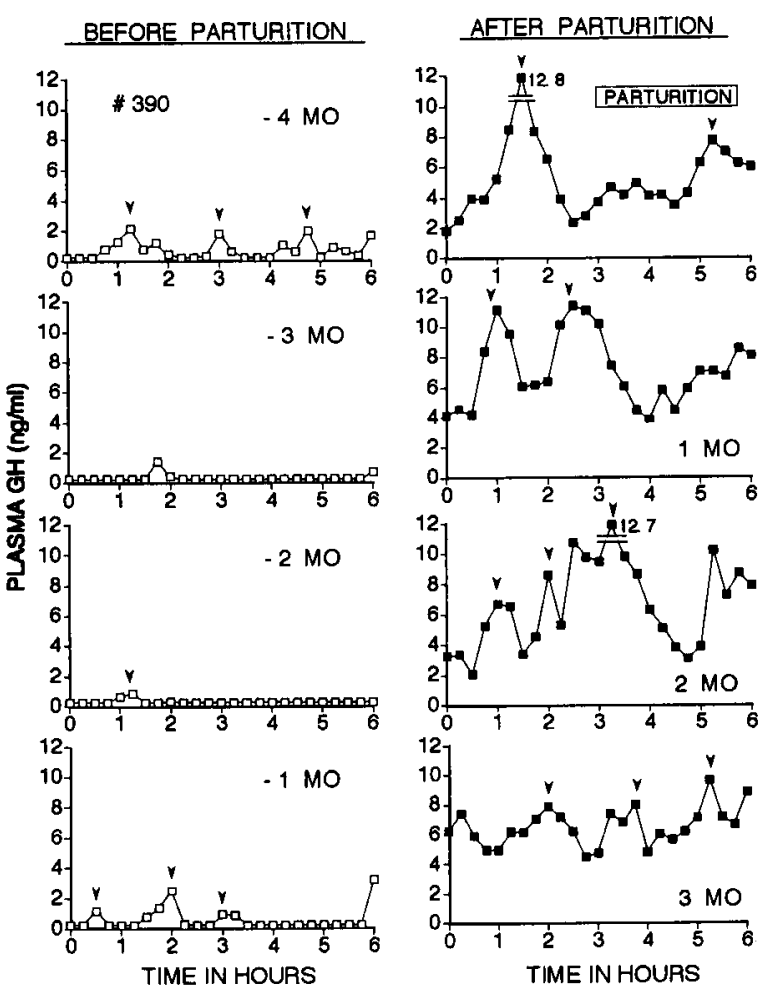

Fig. 1. Episodic profiles of plasma GH throughout gestation and after parturition in a goat. The blood samples were collected every month from 4 months before ( -4 mo: 1 month of gestation) to 3 months after parturition $(3 \mathrm{mo})$. The blood samples at parturition were obtained 1 week after parturition. Arrowheads indicate $\mathrm{GH}$ pulses. 

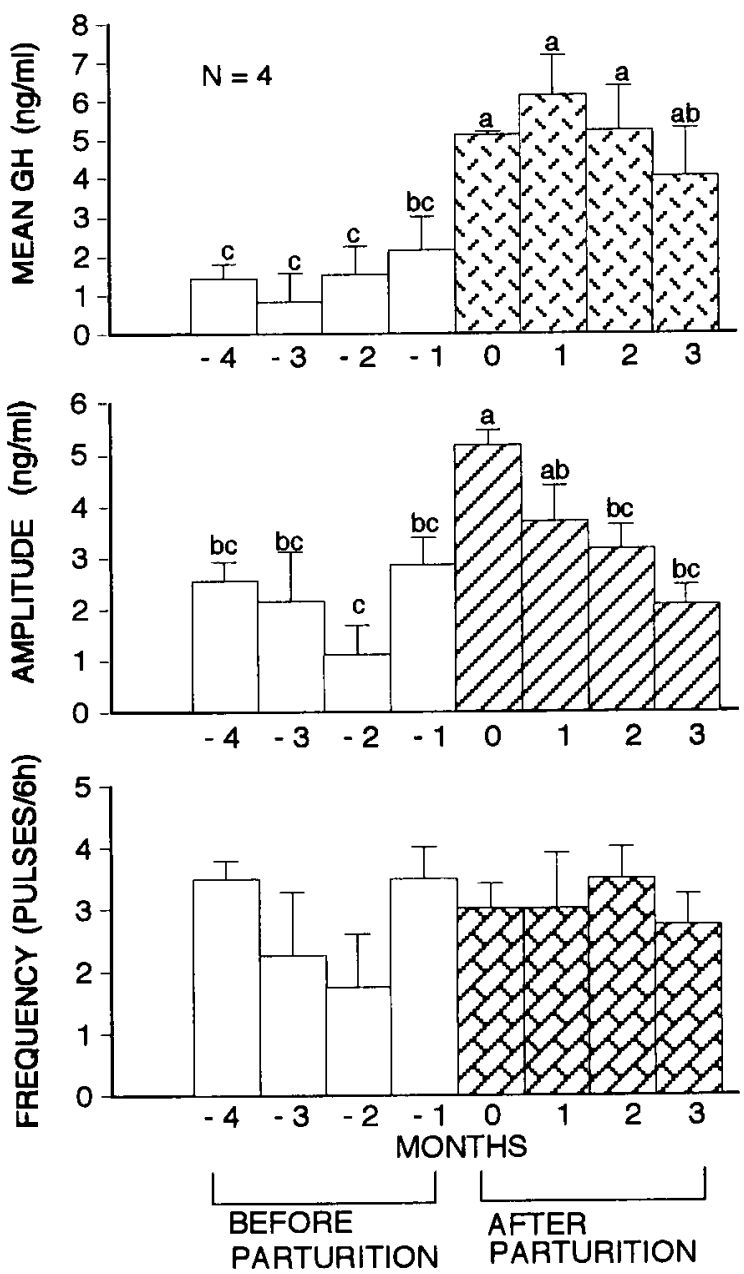

Fig. 2. Average characteristics of GH secretory patterns throughout gestation and after parturition in goats. Each value represents the mean \pm SE for 4 animals. Zero month represents parturition, and the blood samples of 0 month were obtained 1 week after parturition. The different letters on the bars indicate significant differences $(\mathrm{P}<0.05)$.

tion $(\mathrm{P}<0.05)$. The GH pulse amplitude was significantly increased 1 week after parturition $(\mathrm{P}<0.05)$, and the amplitude gradually decreased during the 3 months after parturition. There were no significant differences in GH pulse frequency among the months of gestation and after parturition.

The plasma PRL profiles throughout gestation and after parturition in a representative goat are shown in Fig. 3. PRL was secreted in an irregular pulsatile manner at each month of gestation and after parturition. There were no obvious changes in PRL profiles during gestation, but the PRL se-

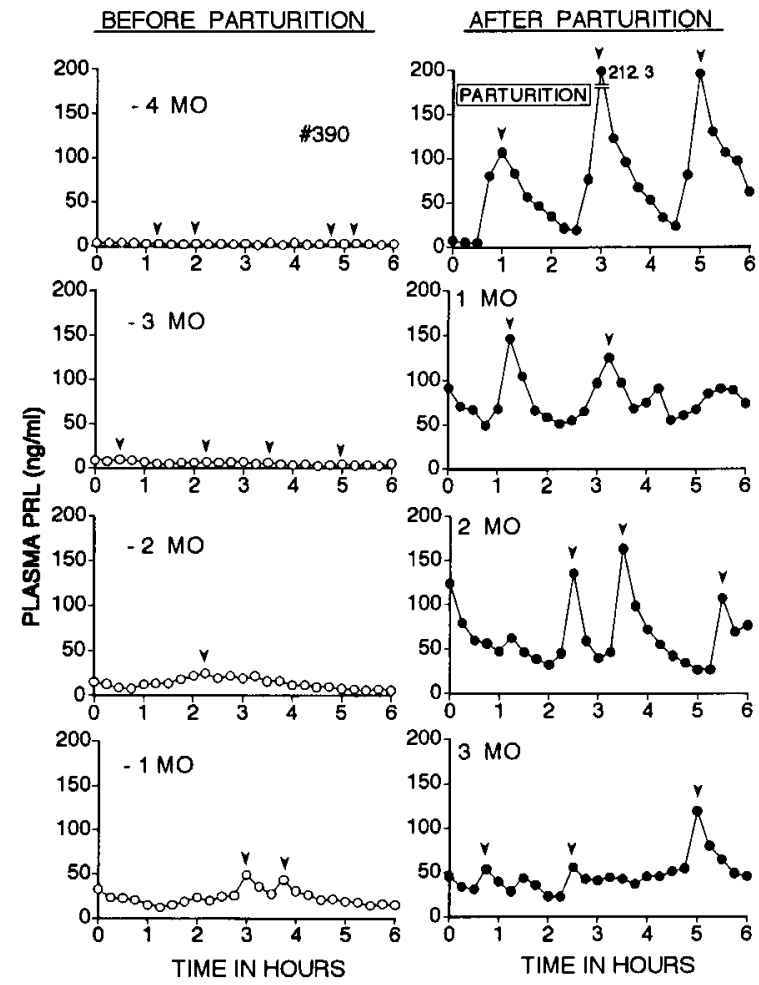

Fig. 3. Episodic profiles of plasma PRL throughout gestation and after parturition in a goat. Arrowheads indicate PRL pulses. Other explanations are the same as in Fig. 1.

cretions were acutely increased after parturition, as observed for the GH profiles. The mean PRL concentrations 1 week and 1 month after parturition were significantly higher than those at each gestation age $(\mathrm{P}<0.05)$ (Fig. 4). The mean PRL concentrations 2 months after parturition were significantly higher than those at each gestation age except for one month before parturition $(\mathrm{P}<0.05)$. The mean PRL concentrations was gradually decreased after parturition. The PRL pulse amplitude 1 week and 1 month after parturition were significantly higher than those at each gestation age $(\mathrm{P}<0.05)$, and the amplitudes gradually decreased during the 3 months after parturition. There were no significant differences in the PRL pulse frequency among the months of gestation and after parturition.

Weekly venipuncture samples during late gestation and after parturition

Plasma GH, IGF-I and PRL concentrations from 8 weeks before parturition to 12 weeks after partu- 

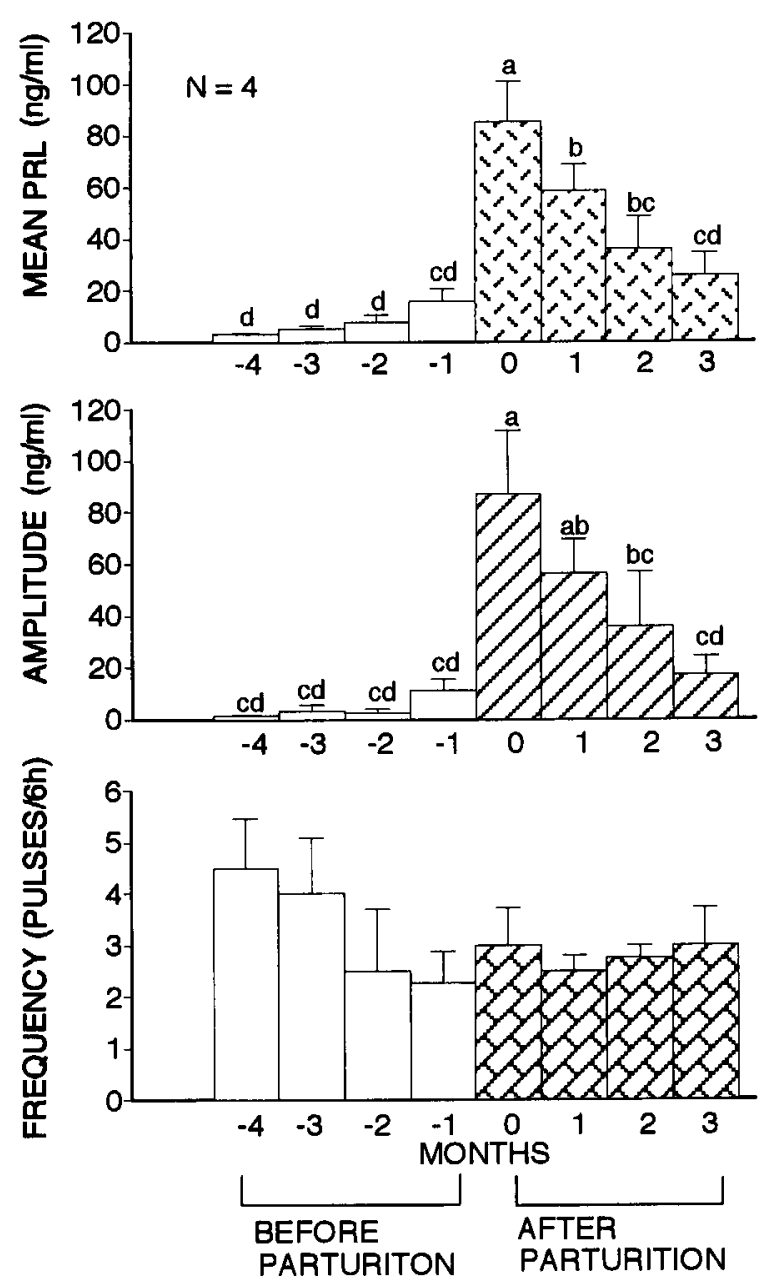

Fig. 4. Average characteristics of PRL secretory patterns throughout gestation and after parturition in goats. Each value represents the mean \pm SE for 4 animals. Other explanations are the same as in Fig. 2.

rition in goats are shown in Fig. 5. The plasma $\mathrm{GH}$ concentrations increased acutely at the day of parturition $(\mathrm{P}<0.05)$, and the $\mathrm{GH}$ concentrations 2 , $3,7,8,10,11$ weeks after parturition were significantly higher than the pre-parturition concentrations $(\mathrm{P}<0.05)$. In contrast to these results, the plasma IGF-I concentrations 3 to 8 weeks before parturition were significantly higher than the post-parturition concentrations $(P<0.05)$; the IGF-I concentrations in late gestation gradually decreased until the day of parturition. The plasma PRL concentrations acutely increased on the day of parturition $(\mathrm{P}<0.05)$, and the PRL concentrations 1, 2, 3 weeks after parturition were significantly higher than the pre-parturition concentrations $(\mathrm{P}<0.05)$. The PRL concentrations decreased grad-
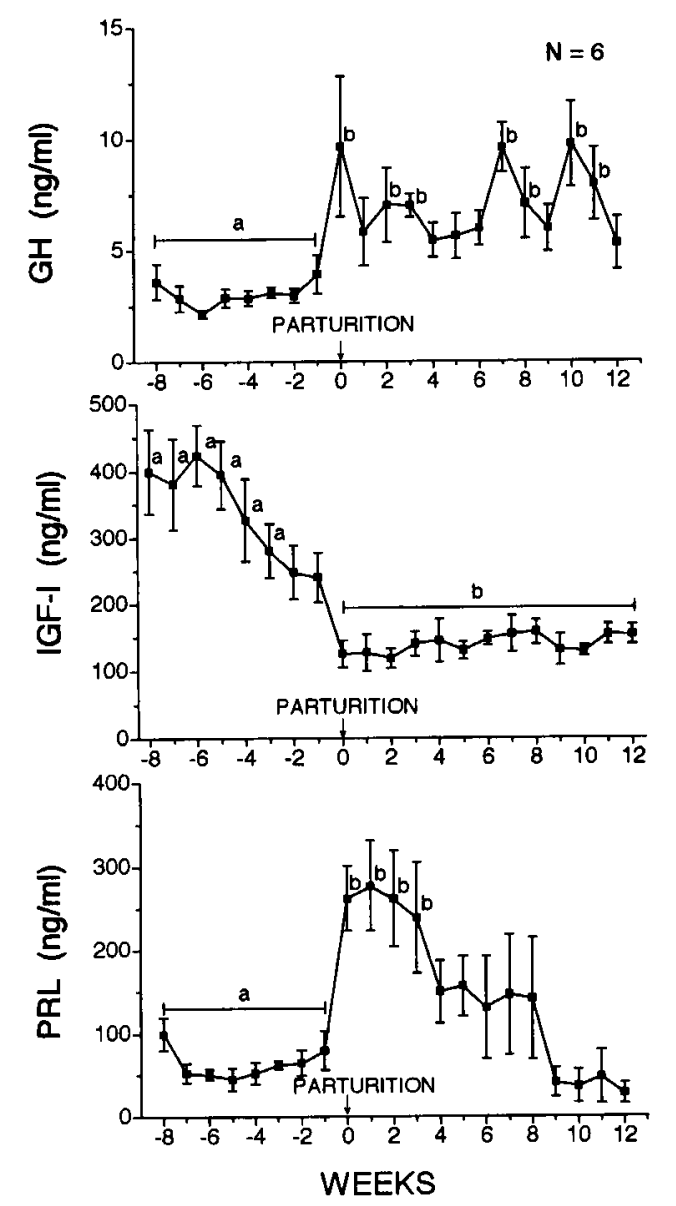

Fig. 5. Plasma GH, IGF-I and PRL concentrations during late gestation and after parturition in goats. Each value represents the mean $\pm \mathrm{SE}$ for 6 animals. The blood samples at parturition were obtained within $3 \mathrm{~h}$ after parturition. a: Significantly different from $b \quad(\mathrm{P}<0.05)$.

ually after parturition.

\section{Weekly venipuncture samples in kids}

Plasma GH, IGF-I and PRL profiles from 1 to 12 weeks after birth in kids are shown in Fig. 6. The plasma GH concentrations 1 and 2 weeks after birth were significantly higher than those during 5 to 12 weeks $(\mathrm{P}<0.05)$, and the plasma IGF-I and PRL concentrations from 1 to 3 weeks after birth were significantly higher than those during 6 to 12 weeks and 5 to 12 weeks, respectively $(P<0.05)$. There were no significant differences in these hormone concentrations between male and female kids (not shown). 

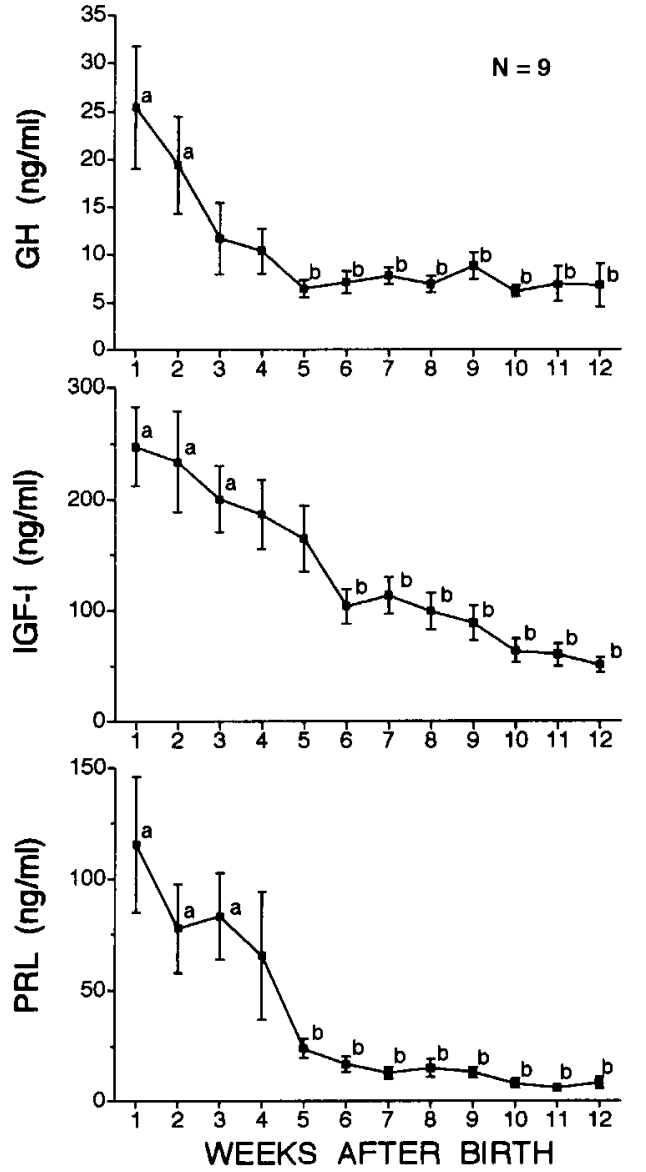

Fig. 6. Plasma GH, IGF-I and PRL concentrations in growing kids. The blood samples were collected weekly from 1 to 12 weeks after birth. Each value represents the mean \pm SE for 9 animals. a: Significantly different from b $(\mathrm{P}<0.05)$.

\section{Discussion}

In rats, the pituitary GH content and GH mRNA increase at midpregnancy [28], and plasma GH levels increase progressively during pregnancy [2830]. However, serum GH levels in humans did not increase, or rather the GH levels declined during the second half of pregnancy [31-38]. No obvious changes in $\mathrm{GH}$ profiles among each month of gestation were observed in the goats of the present study, and these GH profiles for goats during the gestation period seem to be similar to those of humans.

The increase in GH secretion after parturition coincided with the previous results reported in cattle [4, 5, 7-9]. In cows, serum GH acutely increased on the day of calving, and the mean serum GH during the week after parturition was higher than that in prepartum [7]. However, in our study, we also showed that the GH concentrations in nursing goats remain elevated until at least 3 months after parturition. These increased plasma GH levels during the postpartum period are thought to be associated with lactation, and our present findings suggested that these elevated $\mathrm{GH}$ concentrations are caused mainly by an increase in the amplitude of the GH pulses.

The secretion of PRL was acutely enhanced after parturition, although there were no obvious changes in the PRL profile throughout gestation. An acute elevation of the plasma PRL level 2-3 days before parturition was reported in cows [4-8] and goats [6]. The present elevations of mean PRL concentrations after parturition were associated with an increase in the amplitude of PRL pulses. The increase in the PRL level around parturition was shown to be required for the initiation of lactation in ruminants $[15,16]$, and the elevated PRL concentrations around parturition decreased to pre-parturition levels within 5 days after parturition in non-nursing cows [6, 7]. However, in our study, the elevated PRL levels did not decrease rapidly as in cows [4-8], and the elevated levels gradually decreased with time after parturition. These differences are thought to be derived from the stimulation of suckling by kids, since the suckling stimulates a PRL release in goats [6] and sheep [39]. In our experiment, the nursing goats were kept with their kids and allowed to be suckled freely throughout the experiment. The number of suckling episodes by kids in our experiment decreased with time after birth, and the 3-month-old kids were already consuming forage.

Concentrations of PRL in the blood of animals vary between seasons of the year [40]. PRL is more dependent on photoperiod than on temperature, and the long photoperiods of summer are responsible for the high secretion of PRL, and the short photoperiods of winter are responsible for the depressed secretion of PRL [40]. The samples for the episodic characteristics of PRL profiles were obtained from December to July, and weekly samples during late gestation and after parturition were obtained from May to October. Therefore, some part of our results in PRL profiles might be modified by the seasonal effects.

Plasma IGF-I was high during late gestation, and 
the levels gradually decreased until the day of parturition. This result was coincident with the findings in cows [9, 17-20]. A high level of IGF-I during late gestation was also observed in humans [34-38], but not in rats [28]. Maternal IGF-I in blood is synthesized mainly by the liver [41], but the physiologic need for elevated maternal IGF-I during pregnancy is unclear [42]. However, as the stages of pregnancy are considered anabolic to the dam, with increased protein and fat deposition, the high concentrations of IGF-I may play an important role in supporting metabolism during pregnancy in animals. It was also suggested that maternal IGF-I stimulates fetal growth by activating the placental transport of nutrients to fetus [43].

GH levels were low during late gestation in the goats of the present study, nevertheless plasma IGF-I was high at this stage. Placental lactogen (PL) elevates during the last third of pregnancy in goats [44]. PL promotes an IGF-I release [42, 43]. Therefore, high levels of IGF-I at late gestation, in part, might be induced by the PL. There is also a possibility that plasma IGF-I was increased by a $\mathrm{GH}$ variant at the late gestation period in goats. In humans, a GH variant originated from the placenta increases at midgestation [32-38], and this variant can increase plasma IGF-I concentrations [34-38]. Maternal IGF-I levels during gestation were closely related to the corresponding $\mathrm{GH}$ variant, but not to PL in humans $[35,36,38]$. However, it is not yet known whether this GH variant appears during gestation in ruminants. The energy and nutrient requirements in pregnant animals are increased during gestation [1]. And nutritional status plays a major role in determining circulating GH concentrations particularly in the ruminant [3]. However, from our study, it was suggested that pituitary GH release might not be mainly associated with nutritional status during the gestation in goats.

The plasma concentrations of GH, IGF-I and PRL were all high 1 week after birth in kids, and the hormone concentrations decreased gradually thereafter. These changes were in no association with gender. GH $[9,19]$, IGF-I $[9,19]$ and PRL $[45,46]$ are present in milk, and colostrum contains even higher PRL concentrations compared to maternal blood [46]. Thus, neonatal offspring orally consume a substantial quantity of these maternal hormones. There is a possibility that the high levels of these hormones in neonates might be, in some part, derived from milk. However, it is reported that bovine fetal serum GH and PRL increased during pregnancy, and both fetal hormone concentrations at 260 days of gestation were remarkably high [47]. The high concentrations of GH and PRL during the fetal period might have been maintained in the neonates in the present study and declined after birth in association with the development of the hypothalamic regulatory system for pituitary hormone secretion [48]. Physiological roles of high concentrations of plasma GH and IGF-I after birth in kids might be associated with rapid growth in kids at this time, and the high concentrations of plasma PRL might control the tuberoinfundibular dopaminergic neuronal activity in the neonates. However, the significant meanings of these hormonal changes in the neonates remain to be clarified.

In summary, our results show that the secretion of pituitary GH and PRL increase after parturition and that the pituitary GH is negatively related to plasma IGF-I during gestation and the lactation period in goats. The results also show that the plasma concentrations of these three hormones in kids are high after birth and decrease thereafter.

\section{Acknowledgments}

The authors wish to thank Prof. P.V. Malven, Department of Animal Sciences, Purdue University, West Lafayette, IN, USA for a critical reading of this manuscript. We are also grateful to Dr. T. Johke, National Institute of Animal Industry, Tsukuba, Japan, for providing monkey anti-bGH serum, Dr. K. Wakabayashi, the Institute of Endocrinology, Gunma University, Maebashi, Japan for providing goat anti-rabbit IgG serum, goat antimonkey IgG serum and monkey serum, and Prof. Y-I Miyake, Department of Veterinary Science in our University for his help in diagnosis of pregnancy of goats. We also thank the USDA Animal Hormone Program, Beltsville, MD, USA for providing USDA-bGH-B-1, the NIDDK program, Bethesda, MD, USA for providing rabbit anti-IGFI serum (UB2-495) and the NHPP, Rockville, MD, USA for providing NIDDK oPRL-1-3 and rabbit anti-oPRL serum. 


\section{References}

1. Stock MK, Metcalfe J. Maternal physiology during gestation. In: Knobil E, Neil JD (eds.), The Physiology of Reproduction. 2nd ed. New York: Paven Press; 1994: 947-983.

2. Tucker HA. Lactation and its hormonal control. In: Knobil E, Neil JD (eds.), The Physiology of Reproduction. 2nd ed. New York: Paven Press; 1994: 1065-1098.

3. Gluckman PD, Breier BH, Davis SR. Physiology of the somatotropic axis with particular reference to the ruminant. J Dairy Sci 1987; 70: 442-466.

4. Ingalls WG, Convey EM, Hafs HD. Bovine serum LH, GH, and prolactin during late pregnancy, parturition and early lactation. Proc Soc Exp Biol Med 1973; 143: 161-164.

5. Convey EM. Serum hormone concentrations in ruminants during mammary growth, lactogenesis, and lactation: A review. J Dairy Sci 1974; 57: 905917.

6. Johke T, Fuse H, Oshima M. Changes of plasma prolactin level during late pregnancy and early lactation in the goat and the cow. Jap J Zootech Sci 1971; 42: 173-179.

7. Johke $\mathbf{T}$, Hodate $\mathbf{K}$. Bovine serum prolactin, growth hormone, and triidothyronine levels during late pregnancy and early lactation. Jap J Zootech Sci 1977; 48: 772-776.

8. Chew BP, Erb RE, Malven PV, Veenhuizen EL. Plasma concentrations of insulin, growth hormone, and prolactin in pregnant cows subjected to ovariectomy or induced parturition. Am J Vet Res 1980; 41: 544-547.

9. Ronge H, Blum JW. Somatomedin C and other hormones in dairy cows around parturition, in newborn calves and in milk. J Anim Physiol a Anim Nutr 1988; 60: 168-176.

10. Thomas GB, Cummins JT, Cavanagh L, Clarke IJ. Transient increase in prolactin secretion following hypothalamo-pituitary disconnection in ewes during anoestrus and the breeding season. J Endocr 1986; 111: 425-431.

11. Critser JK, Block TM, Folkman S, Hauser ER. Effect of photoperiod on LH, FSH, prolactin and melatonin patterns in ovariectomized prepubertal heifers. J Reprod Fert 1987; 81: 29-39.

12. Evans NM, Hacker RR, Hoover J. Effect of chronobiological alteration of the circadian rhythm of prolactin and somatotropin release in the dairy cow. J Dairy Sci 1991; 74: 1821-1829.

13. Mandiki SNM, Piraux C, Bister JL, Paquay R. Changes in the pattern of prolactin secretion in the postpartum ewe and daily rhythm of prolactinemia during different reproductive states. Annales
d'Endocrinologie (Paris) 1993; 54: 197-201.

14. Albers N, Bettendorf M, Herrmann H, Kaplan SL, Grumbach MM. Hormone ontogeny in the ovine fetus. XXVII. Pulsatile and copulsatile secretion of luteinizing hormone, follicle-stimulating hormone, growth hormone, and prolactin in late gestation: A new method for the analysis of copulsatility. Endocrinology 1993; 132: 701-709.

15. Akers RM, Bauman DE, Capuco AV, Goodman GT, Tucker HA. Prolactin regulation of milk secretion and biochemical differentiation of mammary epithelial cells in periparturient cows. Endocrinology 1981; 109: 23-30.

16. Johke T. Prolactin secretion and lactogenesis in dairy cows and goats. Vlaams Diergeneeskundig Tijdschrift 1986; 55: 251-257.

17. Holland MD, Hossner KL, Tatum JD, King ME, Mauck HS, Odde KG. Serum insulin-like growth factor I profiles in beef heifers with single and twin pregnancies. J Anim Sci 1988; 66: 3190-3196.

18. Vega JR, Gibson CA, Skaar TC, Hadsell DL, Baumrucker CR. Insulin-like growth factor (IGF)-I and -II and IGF binding proteins in serum and mammary secretions during the dry period and early lactation in dairy cows. J Anim Sci 1990; 69: 2538-2547.

19. Shams D, Einspanier R. Growth hormone, IGF-I and insulin in mammary gland secretion before and after parturition and possibility of their transfer into calf. Endocr Reg 1991; 25: 139-143.

20. Hossner KL, Holland MD, Williams SE, Wallance CR, Niswender GD, Odde KG. Serum concentrations of insulin-like growth factors and placental lactogen during gestation in cattle. II. Maternal profiles. Domest Anim Endocrinol 1997; 14: 316-324.

21. Johke T. Effects of TRH on circulating growth hormone, prolactin and triiodothyronine levels in the bovine. Endocrinol Japon 1978; 25: 19-26.

22. Johke T. Radioimmunoassay for bovine prolactin in plasma. Endocrinol Japon 1969; 16: 581-589.

23. Ozawa A, Hodate K, Miyamoto S, Ohtani F, Tsushima T, Johke T. Plasma profiles of insulinlike growth factor-I for 24 hours and after injection of bovine growth hormone in dairy heifers. Anim Sci Technol (Jpn) 1991; 62: 933-938.

24. Daughaday WH, Mariz IK, Blethen SL. Inhibition of access of bound somatomedin to membrane receptor and immunobinding sites: A comparison of radioreceptor and radioimmunoassay of somatomedin in native and acid-ethanol-extracted serum. J Clin Endocrinol Metab 1980; 51: 781-788.

25. Merriam GE, Wachter KW. Algorithms for the study of episodic hormone secretion. Am J Physiol 
1982; 243: E310-E318.

26. Clarke IJ, Fletcher TP, Pomares CC, Holmes JHG, Dunshea F, Thomas GB, Tilbrook AJ, Walton PE, Galloway DB. Effect of high-protein feed supplements on concentrations of growth hormone (GH), insulin-like growth factor-I (IGF-I) and IGF-binding protein-3 in plasma and on the amounts of $\mathrm{GH}$ and messenger RNA for GH in the pituitary glands of adult rams. J Endocrinol 1993; 138: 421-427.

27. Hashizume T, Sasaki K, Kobayashi S, Nitta Y. Intrahypothalamic perfusion of KP102 stimulates growth hormone release in goats. Endocr J 1998; 45: 53-59.

28. Escalada J, Sa'nchez-Franco F, Velasco B, Cacicedo L. Regulation of growth hormone $(\mathrm{GH})$ gene expression and secretion during pregnancy and lactation in the rat: Role of insulin-like growth factor-I, somatostatin, and GH-releasing hormone. Endocrinology 1997; 138: 3435- 3443.

29. Carlsson L, Ede'n S, Jansson J-O. The plasma pattern of growth hormone in conscious rats during late pregnancy. J Endocrinol 1990; 124: 191-198.

30. Jahn GA, Rastrilla AM, Deis RP. Correlation of growth hormone secretion during pregnancy with circulating prolactin in rats. J Reprod Fert 1993; 98: 327-333.

31. Eriksson L, Ede'n S, Fröhlander N, Bengtsson BÅ, von Schoultz B. Continuous 24-hour secretion of growth hormone during late pregnancy- a regulator of maternal metabolic adjustment? Acta Obstet Gynecol Scand 1988; 67: 543-547.

32. Eriksson L, Frankenne F, Ede'n S, Hennen G, von Schoultz B. Growth hormone 24-h serum profiles during pregnancy- lack of pulsatility for the secretion of the placental variant. Br J Obstet Gynaecol 1989; 96: 949-953.

33. Frankenne F, Closset J, Gomez F, Scippo ML, Smal J, Hennen G. The physiology of growth hormone (GHs) in pregnant women and partial characterization of the placental GH variant. J Clin Endocrinol Metab 1988; 66: 1171-1180.

34. Mirlesse V, Frankenne F, Alsat E, Poncelet $M$, Hennen G, Evain-Brion D. Placental growth hormone levels in normal pregnancy and in pregnancies with intrauterine growth retardation. Pediatr Res 1993; 34: 439-442.

35. Caufriez A, Frankenne F, Englert Y, Golstein J, Cantraine F, Hennen G, Copinschi G. Placental growth hormone as a potential regulator of maternal IGF-I during human pregnancy. Am J Physiol 1990; 258: E1014-E1019.

36. Caufriez A, Frankenne F, Hennen G, Copinschi
G. Regulation of maternal IGF-I by placental GH in normal and abnormal human pregnancies. Am J Physiol 1993; 265: E572-E577.

37. Bona G, Aquili C, Pavanini P, Gallina MR, Cigolotti AC, Zaffaroni M, Paniccia P, Mussa F. Growth hormone, insulin-like growth factor-I and somatostatin in human fetus, newborn, mother plasma and amniotic fluid. Panminerva Med 1994; 36: 5-12.

38. Caufriez A, Frankenne F, Hennen G, Copinschi G. Regulation of maternal insulin-like growth factor I by placental growth hormone in pregnancy. Possible action of maternal IGF-I on fetal growth. Horm Res 1994; 42: 62-65.

39. Schirar A, Cognie' Y, Louault F, Poulin N, Meusnier C, Levasseur MC, Martinet J. Resumption of gonadotrophin release during the post-portum period in suckling and non-suckling ewes. J Reprod Fert 1990; 88: 593-604.

40. Malven PV. Chapter 9. Prolactin. In: Mammalian Neuroendocrinology. Boca Raton, Ann Arbor, London, Tokyo: CRC Press; 1993: 119-140.

41. Humbel RE. Insulin-like growth factors I and II. Eur J Biochem 1990; 190: 445-462.

42. Hill DJ. What is the role of growth hormone and related peptides in implantation and development of embryo and fetus. Horm Res 1992; 38 (suppl 1): 28-34.

43. Iwashita M. Physiological significance of IGF-I and its binding proteins on fetal growth and maturation. Acta Obst Gynaec Jpn 1994; 46: 660-672 (In Japanese).

44. Currie WB, Card CE, Michel FJ, Ignotz G. Purification, partial characterization, and development of a specific radioimmunoassay for goat placental lactogen. J Reprod Fert 1990; 90: 25-36.

45. McMurtry JP, Malven PV. Experimental alterations of prolactin levels in goat milk and blood plasma. Endocrinology 1974; 95: 559-564.

46. Nagasawa H. Physiological significance of hormones and related substances in milk with special reference to prolactin: An overview. Endocr Reg 1991; 25: 90-97.

47. Oxender WD, Hafs HD, Ingalls WG. Serum growth hormone, $\mathrm{LH}$ and prolactin in the bovine fetus and neonate. J Anim Sci 1972; 35: 56-61.

48. Walker P, Dussault JH, Alvarado-Urbina G, Dupont A. The development of the hypothalamopituitary axis in the neonatal rat: Hypothalamic somatostatin and pituitary and serum growth hormone concentrations. Endocrinology 1977; 101: 782-787. 